\title{
The Principle of Mutual Trust between Member States in the Area of Freedom, Security and Justice
}

\author{
Clemens Ladenburger"
}

\section{Table of Contents}

A. Introduction

B. The principle of mutual trust in the Area of Freedom, Security and Justice - its foundations and legal effects

C. Exploring possible corollaries of mutual trust in the AFSJ

I. Independent authorities as a corollary?

II. Common EU standards on criminal procedure and on penitentiary systems as corollaries?

III. EU membership as a corollary? 387

D. Setting the limits of mutual trust: the roles of the courts and of the EU legislator 389

I. The evolving case law on mutual trust - retrospective and prospective settings

II. The role of the EU legislator: between aspiration and reality

E. The EU's accession to the ECHR: an obstacle to mutual trust or a catalyst for it? 401

F. Conclusion

404

\begin{abstract}
This study discusses, from various angles, the principle of mutual trust between Member States in the Area of Freedom, Security and Justice (AFSJ). As a starting point it refers to three emblematic cases decided by the European Court of Justice: "Aguirre Zarraga", a child abduction case, "Jawo", a case involving a transfer of an asylum applicant under the Dublin III regulation, and "LM", a case concerning a European Arrest Warrant from Poland, called into question by courts in Ireland in the light of problems of judicial independence in Poland. The first section deals with the founda-

* Principal Legal Adviser, Director for Justice and Home Affairs, Legal Service of the European Commission, Brussels, Belgium; Honorarprofessor at Saarland University, Europa-Institut, Germany. All opinions are strictly personal. This is an expanded version of the inaugural lecture held on 21 October 2019 at the Europa-Institut of the Saarland University. The author has been immensely enriched by numerous discussions with his colleagues in the Commission's and the Council's Legal Services. In particular, he owes thanks to valuable comments received from his colleagues Hannes Krämer, Rudi Troosters, Martin Wasmeier and Geert Wils. The study has also benefitted from important research and assistance by Valerie Albus, Gabriele Asta and Sarah Woyciechowski. Nonetheless, the author alone is to blame for any inaccuracies and flaws.
\end{abstract}


tions and legal effects of the principle of mutual trust. Based on a fundamental distinction to be made between the AFSJ and more traditional EU law settings, it argues that the principle of mutual trust is not a freestanding legal requirement but rather a functional construction principle for the AFSJ. The second section explores several possible corollaries of mutual trust - independent authorities, common EU standards on criminal procedure and on penitentiary systems, and EU membership as such and finds that all these are not quite as straightforward corollaries as they may appear at first sight. The decisive meta-corollary seems is respect for the rule of law. The third section looks at how EU law defines the limits to mutual trust and at the respective roles of the case law and the EU legislator in this context. It finds growing convergence between the two European Court in defining limits and proposes a heuristic distinction between retrospective and prospective settings as a guide for further interpretation. High emphasis is placed on the responsibility of the EU legislator in defining appropriate, tailor-made limits to mutual trust. Looking at the legislative reality so far, marked by various inconsistencies, there is ample room for improvement, but this will remain an arduous task as long as the notorious rule of law problems persist in some Member States. The last section is devoted to the perspective of the EU's accession to the ECHR, in the aftermath of Opinion 2/13 in which the Court had relied inter alia on the principle of mutual trust to find the draft accession agreement as incompatible with EU primary law. The article dismisses ideas of a "disconnection clause" or of codifying the "Bosphorus presumption" to overcome the mutual trust objection of Opinion 2/13, and instead recommends a combination of a substantive clause on mutual trust and of procedural means to deal appropriately with cases on mutual trust arising in the Strasbourg Court. The final proposition is that the EU's accession to the ECHR may be seen as a catalyst for mutual trust between EU Member States, promoting the smooth operation of legislative schemes based upon that principle, rather than as an obstacle to it.

Keywords: EU Law, Principle of Mutual Trust, Area of Freedom, Security and Justice, CJEU Aguirre Zarraga, CJEU Jawo, CJEU LM, CJEU Opinion 2/13

\section{A. Introduction}

Over the past 20 years, the European Union has witnessed a spectacular expansion of its law enacted in the "Area of Freedom, Security and Justice" (hereinafter: the "AFSJ"), as the Lisbon Treaty transformed the Union's policies pursued in the areas of asylum and immigration, judicial cooperation in civil and in criminal matters, as well as in police cooperation. In this innovative area of Union law, governed by Title V of the TFEU (which replaced, after extensive overhaul, the previous Treaty provisions stemming originally from the "Third Pillar" of the Maastricht Treaty) no other overarching legal theme has in recent years garnered as much academic attention as the principle of mutual trust between Member States in relation to respecting fundamental rights. No other legal issue has been at the heart of such a significant number of seminal 
judgments of the Court of Justice in this area. At the same time, in every legislative procedure in which the Union's three political institutions seek to build up this AFSJ further, the most important and often also the most divisive issues of negotiation centre around how to concretise mutual trust between Member States and how to set its limits.

This publication assesses this matter through the lens of a practitioner in the Commission's Legal Service, who routinely deals with AFSJ matters both in relation to legislative work and in cases, mainly preliminary references, before the European Court of Justice. This publication will address four aspects of the principle of mutual trust between Member States in the AFSJ:

1. The foundations and legal effects of the principle of mutual trust in the AFSJ

2. The corollaries of mutual trust in the AFSJ

3. How to set the limits of mutual trust: which are, or should be, the roles of the courts and of the EU legislator; and finally

4. The perspective of the EU's accession to the ECHR: an obstacle to mutual trust or a catalyst for it?

For legal scholars and practitioners alike, one of the most fascinating features of this area of Union law is that it combines substantially diverse and heterogeneous topics and sectors, across the three traditional branches of criminal, civil, and administrative law (the latter in several sub-branches including asylum and migration, as well as police and customs). In these three branches of law, the EU has developed innovative legal schemes of interaction between Member States' authorities, leaving the traditional patterns of international cooperation far behind and affecting profoundly those parts of the Member States' legal systems which had, until the end of the 90's, been considered largely exempt from "Europeanisation". It is tempting but also challenging to try to distil common features, or even common methods and tests, permeating EU legislation and case law across these substantially different areas of the law.

To set the scene for the study, one may recall three "hard cases" the European Court of Justice had to decide upon, which concerned the issue of mutual trust between Member States and its limits.

A child abduction case: Aguirre Zarraga. ${ }^{1}$ The facts of this case are as follows: a Spanish father and a German mother separated and subsequently litigated fiercely about where their 10 year old child should live: in Spain, with the Spanish father where the couple had lived before and where the father was awarded sole custody by the Spanish courts, or in Germany where the mother moved and where she subsequently resided with the child, after having unlawfully transported the child with her at the end of summer vacations. Germany was also the child's preferred place of residence that was expressly noted by the child herself before the German courts. As always in such tragic child abduction cases, the courts are bound by the rules contained in the Hague Convention of 1980, and, as often here the courts of the two countries disagreed

1 CJEU, case C-491/10 PPU, Joseba Andoni Aguirre Zarraga v. Simone Pelz, ECLI:EU:C: 2010:828. 
about the most suitable place of residence for the child. To resolve these conflicts more efficiently, the EU in 2003 complemented the Hague Convention by the so-called "Brussels II a" Regulation, ${ }^{2}$ which introduced a severe means of deterring child abductions whereby if the courts of the country whereto the child was illegally abducted refuse to execute a judgment from the country of last habitual residence, then the courts from that latter country may issue a "certified judgment ordering immediate return" and this must be executed. In other words, the Brussels II a Regulation resolutely granted the court of the last habitual residence the last word. The question in the "Aguirre Zarraga" case was whether this principle was also applicable in a case where the Spanish court had not made any reasonable effort to hear the child before rendering its judgment, and where it made a false statement in the certified judgment holding that the child was heard when in fact she was not. Nonetheless, the European Court of Justice was clear in its stance and held that the child must be returned to Spain. The Court relied upon a clear stipulation in the Brussels II a Regulation, a rule without exceptions needed in order to deter child abductions. It invoked mutual trust, as was also highlighted in the recitals of the Regulation. Judicial protection and fundamental rights scrutiny, in particular the best interest of the child, fall exclusively on the courts of last habitual residence. The judgment has been criticised by scholars. ${ }^{3}$

A Dublin case on transfer of asylum applicants: Jawo. ${ }^{4}$ The facts of this case are as follows: Mr Jawo, a national of Gambia, arrived in Italy in 2012 and then subsequently moved to Germany, where he applied for asylum. The German authorities became aware of the fact that he had first entered the EU through Italy, and as such, they applied the "Dublin III" Regulation ${ }^{5}$ and, once Italy had become the responsible State by not reacting to a "take back" request, ordered Mr Jawo's transfer to Italy. When, on Mr Jawo's appeal against the transfer decision, the case reached the VGH Baden Württemberg, the judges in Mannheim read drastic reports about how, in Italy, asylum seekers were supposedly left to misery by the State, not during the asylum procedure, but after they have been granted full refugee status, simply because Italy allegedly lacked an adequate system of social assistance for people in need, for both Italians and foreigners alike. For indigent Italians however, this was compensated through help provided by the individual's family, but that private safety net did not exist for indigent refugees. It was common ground in the case that Italy did fulfil its legal obligation of equal treatment of refugees and nationals as regards to social assistance, as foreseen by substantive EU asylum law (the "Qualification Directive") ${ }^{6}$ and the Geneva Convention. In the light of those reports on the situation in Italy, the question referred to the Court of Justice was whether a Dublin transfer must be

2 Regulation 2201/2003 concerning jurisdiction and the recognition and enforcement of judgments in matrimonial matters and the matters of parental responsibility, repealing Regulation (EC) No. 1347/2000, OJ L 338 of 23/12/2003, p. 1.

3 Bartolini, CMLR 2019/56, pp. 91-120.

4 CJEU, case C-163/17, Abubacarr Jawo v. Bundesrepublik Deutschland, ECLI:EU:C: 2019:218.

5 Regulation 604/2013, OJ L 180 of 29/06/2013, p. 31.

6 Directive 2011/95, OJ L 337 of 20/12/2011, p. 9. 
blocked if the person concerned, in case of being recognised as a refugee, would be exposed in Italy, in view of the living conditions then to be expected, to a serious risk of inhuman or degrading treatment. The Court of Justice gave a very nuanced answer. It first clarified that the Charter did apply to this question, i.e. that recognised refugees must not be exposed to inhuman treatment. It recalled its earlier judgment in "N.S." on the Dublin regulation, based on mutual trust between Member States and creating a presumption that fundamental rights will be respected, and on the limits to that presumption in case of systemic flaws in the asylum procedure or the reception conditions for asylum seekers. Then the Court clarified that the limits to mutual trust set out in "N.S.", subsequently codified in Article 3 (2) of the "Dublin III" Regulation, were not exhaustive, and applied by analogy the test formulated in its case law on the European Arrest Warrant, ${ }^{8}$ under which the courts, when reviewing a transfer decision, must assess risks of inhuman or degrading treatment which may be "systemic or generalised, or which may affect certain groups of people". Even though it was not strictly necessary given the facts of the case, ${ }^{9}$ the Court went a step further by stressing that "it cannot be entirely ruled out that an applicant for international protection may be able to demonstrate the existence of exceptional circumstances that are unique to him" (emphasis added) to prove a risk of inhuman or degrading treatment. On the other hand, several elements of the judgment convey the Court's concern not to interpret the exception too widely: relying on Strasbourg case law, the Court ruled that Dublin transfers may only be blocked if the court finds that the particular applicant runs a real risk of inhuman treatment because he would find himself in a "situation of extreme material poverty" in Italy. The Court noted at length all that was not sufficient to block a transfer: neither situations characterised even by a high degree of insecurity or a significant degradation of the living conditions of the person concerned, nor the reported fact that help which indigent Italians receive from their families was lacking for refugees, nor shortcomings in integration programmes for refugees, nor the mere fact that social protection and/or living conditions are more favourable in Germany than in Italy. The Jawo judgment clearly leaves the national courts considerable scope for appreciation in individual cases. The VGH Baden-Württemberg ultimately ruled in the Jawo case that adult men in good health could be transferred to Italy. ${ }^{10}$

A European Arrest Warrant issued by Poland: the "LM" case. ${ }^{11}$ The facts of this case are as follows: in 2012, Ireland received a European Arrest Warrant from Poland, ordering Mr LM to be surrendered to Poland so that he could be tried for drugs trafficking offences. In 2017, LM was arrested in Ireland. In principle, there was nothing wrong with the European Arrest Warrant itself - one of thousands issued by Poland

7 CJEU, case C-411/10, N.S., ECLI:EU:C:2011:865.

8 See references below, fn. 13 and 14 .

9 See below, section $3 \mathrm{~b}$ ).

10 Judgment of 29 July 2019, ECLI:DE:VGHBW:2019:0729.A4S749.19.00. On this matter, see also the parallel judgment in CJEU, joined cases C-297/19, C-318/17, C-319/17 and C-438/17, Ibrahim and others, ECLI:EU:C:2019:219, rendered on the same day as the "Jawo" judgment.

11 CJEU, case C-216/18 PPU, LM, ECLI:EU:C:2018:586. 
and other Member States across Europe each year. However, the High Court in Dublin was alerted that in 2017 the European Commission had found, in the Article 7 TEU procedure, a "clear risk of a serious breach by Poland of the Rule of Law principle”, inter alia due to severe attacks on the independence of the courts. The High Court asked the Court of Justice whether in such a situation it could refuse to execute the Polish EAW. In particular, it wondered about the systemic nature of the rule of law breach, potentially affecting the entire justice system in Poland. Would this warrant ipso facto mean that Mr LM could not be surrendered to Poland, or should Ireland still assess specifically for Mr LM whether also be would face a risk of unfair trial for those drugs trafficking charges? And should the Irish Court really still turn to the Polish judiciary, despite the generalised problems of independence affecting it, to ask further questions whether there would be a fair trial for Mr LM? In other words, would the second step of the assessment set out in the seminal judgment "Aranyosi and Caldararu"12 and the procedural obligation of dialogue, also apply in this setting? The Court of Justice ruled that a risk of violation of the right to a fair trial in the issuing Member State could indeed warrant a non-execution of a European Arrest Warrant, just as a real risk of inhuman or degrading treatment in the prisons of the issuing State could. The fundamental right to a fair trial as is laid down in Article 47 of the Charter was thus placed on the same level as the right enshrined in Article 4 of the Charter, although it is not an absolute right unlike Article 4. Crucially, the Court of Justice did not accept that systemic deficiencies potentially affecting the independence of any Polish court could suffice as adequate grounds for not executing the European Arrest Warrant, which would have come down to a power of individual executing courts to consider the European Arrest Warrant scheme de facto suspended in relation to Poland. Instead, the Irish Court would still have to determine, specifically and precisely, whether Mr LM, having regard to his personal situation and the factual context including the nature of the offence, would run such a risk of unfair trial if surrendered to Poland. What is more, the Court of Justice also required that the Irish authorities contact their Polish counterparts to request specific information if it was considering to refuse an execution of an EAW. In doing so, the Court thus struck a delicate balance between respect for a fair trial and keeping the EU's most powerful mechanism of judicial cooperation, based on mutual trust, in function. If no Polish EAW could be executed anymore, there would be immense risks of impunity in Europe. It is interesting to note that, based on the LM judgment, the High Court, confirmed by the Irish Supreme Court, eventually found against Mr LM and he was ultimately surrendered to the Polish authorities.

What is common in these three examples, taken respectively from civil, administrative and criminal law contexts, is that they are all concerned with a transfer of an individual from one Member State to another, bound to take place pursuant to an EU scheme of cooperation based upon the principle of mutual trust, in very fundamental rights-sensitive circumstances. In each case, the authorities and courts of one Member 2016:198. 
State are called upon to determine whether the transfer to the other Member State may proceed, despite information pointing to a risk of violation of that human being's fundamental right in case of such transfer.

\section{B. The principle of mutual trust in the Area of Freedom, Security and Justice - its foundations and legal effects}

In its Opinion 2/13 on the EU's accession to the ECHR, the Court of Justice clearly referred to "mutual trust" between Member States as a legal principle, a general principle of EU law and one of constitutional rank. As the Court elucidated, "that principle requires, particularly with regard to the area of freedom, security and justice, each [Member State], save in exceptional circumstances, to consider all the other Member States to be complying with EU law and particularly with the fundamental rights recognised by EU law". ${ }^{13}$ Most importantly, the Court derives from this principle that the Member States "may under EU law, be required" to presume that fundamental rights have been observed by the other Member States so that, "save in exceptional cases", they may not check whether the other Member State has actually, in a specific case, observed fundamental rights. ${ }^{14}$ It should be noted that the Treaties themselves, as reformed profoundly by the Treaty of Lisbon, do not refer to a principle of mutual trust. They do enshrine the "principle of mutual recognition" as underlying judicial cooperation in civil and in criminal matters (see Articles 70, 81, 82 TFEU) - a legal principle which found its way into the Lisbon Treaty after having been politically highlighted by the Tampere European Council of 1999 as the "cornerstone" of judicial cooperation. Interestingly, that legal principle and the Treaty Articles enshrining it are not mentioned in Opinion 2/13. Prior to Opinion 2/13, it had been the EU legislator which, in recitals to legislative acts establishing schemes of mutual recognition of judicial decisions, had begun to refer to a "principle of mutual trust" as a basis for inspiring the legislation. ${ }^{15}$ The Court of Justice had every so often quoted such recitals, ${ }^{16}$ and occasionally referred to mutual trust without such explicit legislative language, but without qualifying it as a legal principle. ${ }^{17}$

This section discusses the theoretical foundations of the principle as found in Opinion 2/13 and its legal effects, including, in particular, the question of whether and in

13 Opinion 2/13, ECLI:EU:C:2014:2454, point 191.

14 Point 192. The Court also notes that pursuant to the principle of mutual trust the Member States may be required not to demand a higher level of national protection of fundamental rights from another Member State than that provided by EU law.

15 See, e.g., recitals 16 and 17 of Regulation 44/2001 (Brussels I), OJ L 12 of 16/1/2001, p. 1; recital 21 of Regulation 2201/2003 (Brussels II a), OJ L 338 of 23/12/2003; recital 10 of Council Framework Decision 2002/584/JHA (European Arrest Warrant), OJ L 190 of 18/07/2002; recital 5 of Council Framework Decision 2008/909/JHA (mutual recognition of judgments in criminal matters), OJ L 327 of 05/12/2008, p. 27.

16 CJEU, case C-195/08 PPU, Inga Rinan, ECLI:EU:C:2008:406, at point 50.

17 See, inter alia, CJEU, joined cases C-187/01 and C-385/01, Gözutök and Brügge, ECLI:EU:C:2003:87, at point 33; CJEU, case C-399/11, Melloni, ECLI:EU:C:2013:107, at point 63; CJEU, case C-411/10, N.S., ECLI:EU:C:2011:865, at point 79. 
which circumstances it may be justiciable. Indeed, resolute though this passage of Opinion 2/13 is worded, such questions still remain.

To analyse them, one should first turn to a more general question: is "mutual trust" a unique concept in the AFSJ, or is it essentially the same "principle" as is already known from other areas of established EU law, particularly from internal market cases? ${ }^{18}$ The "Bouchara" judgment of $1989^{19}$ is perhaps the earliest clear case in point. It referred to "a more general principle of mutual trust" as implying that the free movement of goods prevents a Member State from requiring that product verifications already conducted in another Member State be repeated upon importation. In recent times, the principle of mutual trust has again been quoted by the Court of Justice in seminal judgments outside the AFSJ such as "Acbmea". ${ }^{20}$ Moreover, the Court in Opinion 2/13, formulated that the principle requires "particularly with regard to the area of freedom, security and justice" each Member State to consider the others fundamental rights-compliant. One might thus be easily tempted to take Opinion 2/13 as evidence for an overarching constitutional principle, which should be one and the same, across the various areas of EU law, for all purposes of legal analysis.

This study nonetheless argues in favour of the opposite view. It is submitted that there is one crucial difference which renders cases on mutual trust in the AFSJ distinct and different from other settings of EU law in which the principle has been relied upon. That crucial difference may be termed the reverse effects on individuals and their fundamental rights. While in the internal market cases such as Bouchara, the principle of mutual trust between Member States' authorities has systematically worked in favour of individual rights of the market operators, in the AFSJ the principle most often ${ }^{21}$ adversely affects fundamental rights of the individuals concerned, since it excludes a second check of the respect of such rights in the courts of another Member State. This, in our view, justifies taking some distance from the internal market setting when analysing the roots and legal effects of the principle of mutual trust in the AF$\mathrm{SJ}^{22} \cdot{ }^{23}$ For all purposes of legal analysis, one should distinguish the principle of mutual trust in this area of FSJ from that invoked in other areas, and one should define its legal effects, its justiciability and, indeed, its rationale, in a specific manner. As such, the following conclusions can be derived from this.

18 Instructively on the origins of the mutual trust principle, Blanchet, at pp. $183 \mathrm{ff}$.; Regan, at pp. $231 \mathrm{ff}$.

19 CJEU, case 25/88, Bouchara, ECLI:EU:C:1989:187.

20 CJEU, case C-284/16, Achmea, ECLI:EU:C:2018:158.

21 Admittedly, sometimes mutual trust-based rules also work for the benefit of the individual. See, e.g., the transnational ne bis in idem rule enshrined in Article 54 of the Convention implementing the Schengen Agreement.

22 Some schemes of mutual recognition established by the EU legislator outside the policies covered by Title V of the TFEU are nonetheless akin to those based on Title V. One example is Directive 2010/24 concerning mutual assistance for the recovery of claims relating to taxes, duties and other measures, which was interpreted in case C-134-17, Donnellan, ECLI:EU:C: 2018:282.

23 See also Schwarz, p. 139. 
Firstly, in the AFSJ, the mutual trust principle should not be viewed as a freestanding legal requirement, to be observed by Member State authorities in their cooperation with respect to one another. ${ }^{24}$ It only becomes applicable once and to the extent that the EU legislator has enacted concrete schemes of cooperation between Member States. Mutual trust can be considered a principle of interpretation of such legislative rules, but it has no direct effect in the absence of legislation. This conclusion follows from the basic requirement that restrictions or limitations to fundamental rights must have a basis in legislation. The wording of Opinion 2/13, though not consistent in this respect, seems, in its key passages, to confirm this point: the Court notes that EU law "may require" one Member State to presume that fundamental rights have been observed by another Member State and may hence bar the first Member State from checking the second Member State has actually, in a specific case, observed fundamental rights. It must, however, be the decision of the EU legislator to enact schemes under which such obligation of the first Member State towards the second comes into existence.

If the intervention of the EU legislation is indispensable in creating a scheme of cooperation based on mutual trust, then it follows, next, that the extent and the limits of mutual trust are modulable - indeed highly modulable - by the EU legislator from area to area and even from scheme to scheme. ${ }^{25}$ Mutual trust between Member States may thus have quite different implications in asylum law as compared to criminal judicial cooperation or to civil law. Even within one sector of the law alone, the EU legislator may foresee different degrees of mutual trust dependent on the respective scheme. As we shall discuss further on, such graduations in the extent of trust may or may not be rational or appropriate, but undeniably they exist: there are different rules for the extent of mutual recognition and mutual trust for child abduction matters as compared to commercial law cooperation or as compared to succession matters.

Furthermore, one may wonder whether the principle of mutual trust might ever become justiciable in such a manner that the Court of Justice could strike down EU legislation for having required "too little" trust between cooperating authorities. The phrase "save in exceptional cases" in Opinion 2/13 could be read as implying that the legislator might contravene EU primary law by laying down rules which allow a doublecheck of respect for fundamental rights in a significant number of cases, such that they no longer appear as "exceptional" in nature. In practice, it appears unlikely however that the Court would exercise such scrutiny, both for want of manageable legal parameters of what can characterise an "exceptional case" and given the high authority that one should accord to the EU legislator in setting the procedures and modalities for protecting fundamental rights in cross-border cooperation schemes. After all, by striking down EU legislation on such grounds, the Court of Justice would be censuring

24 Likewise, Lenaerts, p. 811 ("only the EU legislative institutions may give concrete expression to the principle of mutual recognition"); Maiani/Migliorini, pp. 11, 32; Nettesheim, p. 12; Prechal, p. 92 agrees for the present state of the law, but does not exclude that mutual trust may eventually become a "self-standing obligation".

25 This point is confirmed by Maiani's and Migliorini's impressive study spanning across the various sectors of the AFSJ. 
the EU legislator for having organised too great a degree of protection for fundamental rights.

Finally, it must be noted that the specificity of cooperation schemes in the AFSJ is also relevant in reflecting on the theoretical foundations, the roots and the rationale of the mutual trust principle. In the academic discourse on this topic over the last few years, different theories have been advanced. Koen Lenaerts has proposed to derive the principle of mutual trust from the basic constitutional principle of equality between Member States, which is now expressly enshrined in the Treaties (Article 4 (2) TEU). ${ }^{26}$ One may wonder how far this proposed foundation really leads. Equality of Member States before the Treaties, similar to the general concept of equality before the law, forbids treating comparable situations differently in the absence of objective justifications. The EU legislator could of course not foresee at an abstract level that, when Member State A cooperates with Member States B and C in executing their judicial decisions or in transferring persons to them, Member State B deserves less trust in its capacity to observe fundamental rights than Member State C. However, such legislation does not exist. In fact, the real issue is to what extent two Member States should, or must, presume each other's human rights observance when they cooperate cross-border with each other. In such cooperation, the two Member States find themselves in two rather different situations: i.e. one is in the role of issuing a European Arrest Warrant for prosecution and, in the future, bringing the person surrendered to trial in fairness and, possibly imprisoning him in conditions of dignity; the other is in the role of having to decide whether or not to execute the warrant and surrender the person to that country, on the basis of the limited information at its disposal and despite possible concerns about respect of fundamental rights in the other Member State. While equality of Member States as a legal norm in its classic sense would offer no suitable standard for resolving this situation, since each of the two Member States finds itself in a different, not comparable situation, Koen Lenaert's argument is actually based on equality in the sense of an equal commitment of all Member States to the Union's values in Article 2 TEU and to the Charter (when they implement Union law). ${ }^{27}$ Such equal commitment is undoubtedly documented by Member States' adhesion to the Treaties, but it should be renewed by deeds over time.

Others have argued that mutual trust between Member States is an emanation of the general principle of sincere cooperation between Member States. ${ }^{28}$ That general principle has given rise to a wide variety of procedural and behavioural obligations incumbent on a Member State where it cooperates with another Member State, or with the Union institutions. No doubt the principle is also applicable where the authorities of two Member States cooperate within Dublin or European Arrest Warrant procedures, and it may guide the interpretation of such schemes of cooperation. However, the principle of sincere cooperation could hardly be a sufficient normative basis for curtailing the protection of fundamental rights of persons bound to be sent from one

26 Lenaerts, pp. $807 \mathrm{ff}$.

27 The author wishes to thank Koen Lenaerts for having pointed out this aspect to him.

28 Prechal, p. 92. 
Member State to another. By its very structure as a procedural and behavioural principle governing bilateral cooperation authorities, it lacks the legal force that would be necessary to prohibit one Member State from proceeding to those verifications that the ECHR or its own constitutional law would normally impose on it in order to ensure respect for fundamental rights when cooperating with another Member State.

The most appropriate explanation of mutual trust between Member States is rather, we would submit, that of a functional construction principle for the AFSJ. ${ }^{29}$ For this area without internal borders to function efficiently, an authority of one Member State, required to cooperate with that of another, cannot in each case dig deeply into whether a fundamental rights violation has already occurred or may in the future occur in the other State. Some horizontal division of tasks and attribution of legal responsibilities for protecting fundamental rights is simply needed between the two sides. Trust is by definition an attitude we deploy when we deal with imperfect knowledge. ${ }^{30}$ When cooperating across national borders, authorities necessarily face information gaps as regards to the concrete situation in the other Member State. The question then arises as to how an authority of one Member State should act when faced with allegations of possible fundamental rights violations that may have taken place in the past or that may still occur in the other Member State. When defining the division of tasks and responsibilities of both cooperating sides, one must take into account, on the one hand, the idea that violations of EU fundamental rights must be avoided as much as possible, but that, on the other hand, cooperation must be swift and smooth by design. Otherwise, an AFSJ cannot be sustained where internal borders have been largely abolished - including for asylum seekers making illicit secondary movements, for parents taking their children with them illegally, indeed even for persons under criminal investigation.

Mutual trust, understood as a functional construction principle for the AFSJ, works to legitimise fundamental choices that the EU legislator must make when building the AFSJ and establishing schemes of legislation within that area without internal borders. The mutual trust principle is what enables the legislator to discharge administrative and judicial authorities from probing into each and every allegation of a risk to fundamental rights when called upon to cooperate by agreeing to execute a judgment or decision from another Member State or by surrendering a person to the jurisdiction of that State. This legitimising role becomes important when the Union will, upon its accession to the ECHR, explain and defend its legislative schemes in the European Court of Human Rights (see section 4 below). The flip side of this is to make the mutual trust principle fertile for explaining and interpreting the rules of cooperation

29 A similar theoretical foundation is proposed by Jacqué, La confiance mutuelle, who sees mutual trust in the AFSJ as an expression of horizontal federalism, similar to that developed within the United States. See also DanwitzEuR 2020/1, pp. 61-89, proposing to anchor the principle of mutual trust in Articles 2 and 3 TEU. This may be said to overlap with our understanding of a functional construction principle, in that Article 3 (2) TEU enshrines the construction of an AFSJ as one of the EU's prime objectives.

30 Schwarz, p. 131. 
laid down in the respective legislative scheme, i.e. rules defining which authorities are entitled to cooperate and hence benefit from trust by the other side, which are the substantive requirements to be fulfilled for a person to be handed over from one Member State to another, how the guarantees established in the legislation to secure the rights of that person should function and, last but certainly not least, which are the cases allowing or even requiring the authority to refuse the transfer of a person or execution of a judgment given a real risk of violation of a fundamental right.

\section{Exploring possible corollaries of mutual trust in the AFSJ}

In recent years, Koen Lenaerts and other commentators have been emphasising that "mutual trust is not blind trust" and that "trust must be earned". ${ }^{31}$ Or, as Eberhard Schmidt-Aßmann put it, society needs not only trust in the law, but also trust through the law. ${ }^{32}$ This raises the question about the corollaries of mutual trust, i.e. the accompanying conditions which should exist within the law to build up mutual trust and to sustain it. ${ }^{33}$

Reflecting upon these corollaries is all the more important today since, as debates in the European Parliament and negotiations in the Council reveal, the level of mutual trust between Member States is not particularly high at the moment. Certainly it is lower than at the time when the EU started implementing the "Tampere" programme ${ }^{34}$ and adopted its first ground-breaking legislative acts based upon the idea of mutual trust, such as the European Arrest Warrant Framework Decision or the Brussels II a Regulation.

Furthermore, it would seem that in scholarly writing on mutual trust over the last few years, this question has not yet garnered the level of attention that it deserves. As will be discussed further below, what may initially appear to be a straightforward condition for building and expecting mutual trust is, upon closer inspection, far less obvious. Often, the question of the necessary, or at least useful, corollaries of mutual trust in the AFSJ is a multi-faceted one.

\section{Independent authorities as a corollary?}

The first question that may arise is whether some degree of independence of the acting authorities should be a necessary corollary of mutual trust between Member States in the AFSJ. The Court's recent case law on judicial authorities capable of issuing European Arrest Warrants could be read in that way. In the "LM" judgment, ${ }^{35}$ as an obiter dictum, the Court states that "not only the decision on executing a European arrest

31 See Lenaerts, p. 840.

32 Schmidt-Aßmann, in: Weingardt (Hrsg.), pp. 129-149.

33 For a more detailed exposé of reflections contained in this section, see Ladenburger, in: Lenaerts/Bonichot/Kanninen/Naômë/Pojhankoski (eds.), pp. 163 - 176.

34 Set out in the Conclusions of the European Council held in October 1999 and devoted almost exclusively to Justice and Home Affairs.

35 CJEU, case C-216/18 PPU, LM, ECLI:EU:C:2018:586, at points 55 and 56. 
warrant, but also the decision on issuing such a warrant, must be taken by a judicial authority that meets the requirements inherent in effective judicial protection - including the guarantee of independence."

This dictum immediately ignited the debate on whether public prosecutors who, at least in theory, can receive instructions from the Minister for Justice, as is the case in Germany, and are consequently not independent, should still be able to issue European Arrest Warrants. It resulted in the broader question of whether the notion of independence is to be understood in the same sense for prosecutors issuing EAWs as for courts under Article 19 TEU. ${ }^{36}$ Meanwhile, the Court has further clarified the situation, at least for the European Arrest Warrant scheme, ${ }^{37}$ and this piece will not discuss the latest developments in this emerging area of case law. ${ }^{38}$

The question of systemic importance is whether the Court's dictum in "LM" was meant to imply that judicial authorities, cooperating with each other in the AFSJ, can trust each other because and only if they are independent, and if so, whether that assumption is one that should underlie all legislative schemes of judicial cooperation in criminal matters, and perhaps even in civil matters.

It is submitted that the independence of the acting authority is not an indispensable corollary of mutual trust schemes within the AFSJ. Counterexamples of two cooperation regimes based on mutual trust support this argument. The first relates to the Dublin Regulation as a central piece of the Common European Asylum System. The actors who deal with asylum applications are classic administrative authorities, and these are in most legal systems subject to instructions from the Minister of Interior who is accountable to Parliament for the proper implementation of EU and national asylum legislation. Nevertheless, even though these administrative actors are in no respect independent authorities, the Court has underlined that the Dublin Regulation is based upon mutual trust. The second example concerns the mutual assistance scheme under Directive 2010/24 on the recovery of claims relating to taxes, duties and other measures. ${ }^{39}$ Although this scheme is not a part of Title V, the Court held in Don$n$ ellan ${ }^{40}$ that this Directive is also based upon the principle of mutual trust and that its case law on the Brussels I Regulation should be applicable by analogy. However, authorities deciding on customs and tax claims are typically part of the general administration which are subject to the complete instructions of their respective finance ministries. Consequently, as is the case with the Dublin Regulation, the acting authorities under Directive 2010/24 are, for the most part, not independent.

Thus, it is not a precondition for any legislative scheme based on mutual trust between Member States that the cooperating authorities enjoy any particular degree of

36 CJEU, case C-64/16, Associação Sindical dos Juízes Portugueses ECLI:EU:C:2018:117.

37 See: CJEU, joined cases C-508/18 and C-82/19 PPU, OG and PI, ECLI:EU:C:2019:456; CJEU, case C-489/19 PPU, NJ, ECLI:EU:C:2019:849; CJEU, joined cases C-566/19 PPU and 626/19 PPU, $J R$ and $Y C$, ECLI:EU:C:2019:1077; CJEU, case C-627/19 PPU, ZB, ECLI:EU:C:2019:1079; CJEU, case C-625/19 PPU, XD, ECLI:EU:C:2019:1078.

38 For more details on this, see Ladenburger/Albus, in: Sarmiento/Ruiz-Fabri/Hess (eds.).

39 Directive 2010/24 concerning mutual assistance for the recovery of claims relating to taxes, duties and other measures, OJ L 84 of 31/03/2010, p. 1.

40

CJEU, case C-34/17, Donnellan, ECLI:EU:C:2018:282. 
independence. It remains true however that the EU legislator may seek to modulate the degree of trust which it can expect authorities to show towards one another, and consequently, the intensity of mutual recognition, depending on the status of the interacting authorities. What can be observed, for instance, is that EU schemes of mutual trust are much further developed in judicial cooperation in criminal matters than in police cooperation. ${ }^{41}$ Nonetheless, the truly indispensable corollary for any mutual trust scheme is effective judicial protection before independent courts against any decision affecting rights. This must be ensured in both Member States which are involved in a cooperation scheme. Obviously, effective judicial protection is one of the most pivotal elements of the rule of law. That principle cannot be upheld without an independent and efficient judiciary and also without integrity of all State organs, in particular the administration (be it the general administration, submitted to ministerial instruction to ensure parliamentary accountability, or special independent agencies). Ultimately, the rule of law is the one meta-corollary for mutual trust between Member States in the area of FSJ. The much-discussed attacks on it in some Member States explain why mutual trust between Member States is, de facto, at a low point; it is these attacks that currently pose the most serious threat to the functioning of the entire AFSJ. ${ }^{42}$

\section{Common EU standards on criminal procedure and on penitentiary systems as corollaries?}

When the Lisbon Treaty introduced legal bases for minimum harmonisation of certain aspects of criminal procedure, the basic rationale for this was that such harmonisation would strengthen the mutual trust between Member States that is needed to underpin mutual recognition of judicial decisions in criminal matters. As such, common EU standards on criminal procedure are often presented as a corollary of mutual trust.

However, upon closer inspection certain inconsistencies are revealed. To name one, the opt-out from harmonisation in this area which was granted to Denmark and Ireland ${ }^{43}$ does not square with common standards of criminal procedure being a corollary of mutual trust. These Member States, despite not being bound by all the six Directives on criminal procedure adopted post-Lisbon, are nonetheless fully part of the European Arrest Warrant system. In theory, this is illogical as it breaks the link between procedural harmonisation and mutual recognition. In practice, however, this "broken corollary" has hardly ever been perceived as problematic, or even noticed, since the rules and practices on criminal procedures in these Member States, which are of course bound by the minimum requirements of a fair trial pursuant to Article $6 \mathrm{ECHR}$, have not given rise to systemic concerns. Should such systemic deficiencies arise in the future in the criminal law systems of Denmark or Ireland, admittedly the Commission would not have the same possibilities available to it in terms of launching infringement cases as it

41 For details, see Ladenburger, p. 168.

42 In lieu of many more references, see only Bogdandy, in: Kadelbach (ed.), pp. $23-40$.

43 As well as to the United Kingdom until its withdrawal from the EU on 31 January 2020. 
would have towards the remainder of the Member States which are bound by the six Directives. However, if Denmark or Ireland took no action to remedy the deficiencies concerned, the EU legislator could intervene by amending the affected schemes of mutual recognition of judicial decisions which rest on mutual trust. Such a perspective would be far from ideal, however, as it would entail a significant risks of impunity.

In practice however, what has hampered the operation of the European Arrest Warrant much more than the above-mentioned puzzle of variable geometry is the deplorable prison conditions that exist in several Member States. This has proven to be the most significant hurdle in practice when executing European Arrest Warrants. ${ }^{44} \mathrm{Un}$ fortunately, the EU competence for tackling this problem is less clear than that for harmonising rules of pre-trial and trial procedure. In the European Convention of 2002/2003 that established the framework for the Lisbon Treaty, the idea of creating a legal basis for minimum harmonisation for the Member States' penitentiary systems was considered but ultimately rejected, as it was deemed to significantly encroach upon the Member States' sovereignty. True, the Strasbourg Court's case law under Article 3 ECHR, followed meticulously by the European Court of Justice, sets precise requirements for humane prison conditions. Nonetheless, there is uncertainty as to whether this matter could be brought by the legislator within the scope of EU law for the purposes of Article 51 of the Charter. As a result, it is unclear whether the Commission could initiate infringement proceedings against a Member State if its prison conditions were to endanger the functioning of the European Arrest Warrant scheme.

\section{EU membership as a corollary?}

A final issue which warrants closer scrutiny is whether "mutual trust" as a basic underlying construction principle for schemes of cooperation in the AFSJ necessarily implies that cooperation take place exclusively within the EU, i.e. amongst its Member States. Thus, is it fundamental for the principle of mutual trust, in the way the Court has interpreted it, that both cooperation partners are members of the EU, bound by the Charter of Fundamental Rights and submitted to the jurisdiction of the Court of Justice? Opinion 2/13 could be understood as suggesting precisely this, with its sharp dichotomy between trust-based cooperation that the EU legislator may impose on Member States within the EU and the legal relations between other European countries, where the ECHR may provide a trust-limiting framework amenable to full scrutiny by the Strasbourg Court.

This triggers the following question which is of practical importance: are the EU's political institutions subject to constitutional constraints when they envisage negoti-

44 In 2017 alone, 77 EAWs from Romania alone had been rejected by German Courts on this basis, as the order of reference in case C-128/18, Dorobantu, informed the Court of Justice. See also Eurojust's Outcome Report of the College Thematic Discussion on the EAW and Prison Conditions of May 2017, http://www.eurojust.europa.eu/doclibrary/Eurojust-fra mework/ejstrategicmeetings/Outcome\%20report\%20of\%20College\%20thematic\%20dis cussion \%20on\%20EAW\%20and\%20prison\%20conditions\%20(May\%202017)/2017-05 _9197-17_Outcome-Report-on-EAW-and-Prison-Conditions_EN.pdf (14/09/2020). 
ating and concluding international agreements of the EU with third countries by which substantial parts of the AFSJ acquis is extended to third countries?

In fact, the EU has already done so, when it concluded association agreements to extend the Schengen acquis and the Dublin and Eurodac Regulations to Norway, Iceland, Liechtenstein and Switzerland. Consequently, four associated States are treated, for all purposes, like Member States under these EU secondary law instruments. ${ }^{45}$ Moreover, an EU agreement with Norway and Iceland on the surrender procedure, signed in 2006 under the ex-third pillar rules, finally entered into force in late 2019. ${ }^{46}$ It closely replicates the European Arrest Warrant Framework Decision, subject to only two exceptions (the political offence and the nationality exception). However, these four States have neither expressed their commitment to the values enshrined in Article 2 TEU, nor are they bound by the Charter or submitted to the jurisdiction of the Court. In practice, this also means that their courts cannot make a preliminary reference to the Court, and only political dispute settlement mechanisms are provided for in the association agreements.

We would argue that, for historical and geographical reasons, these partial extensions of AFSJ acquis to these four States, which are within the Schengen area, were indispensable and cannot, even in light of Opinion 2/13, be considered as exceeding constitutional boundaries. In addition, the four countries are contracting parties to the ECHR, have incorporated it into their domestic law, and in the past, did not expose any systemic issues in observing ECHR rights. However, the question is now arising anew following Brexit, and with reinforced acuity, as the EU and the UK have commenced negotiations regarding their future relations. A key aspect of these negotiations is on law enforcement cooperation and judicial cooperation in criminal matters. The Commission's recent draft agreement which was published on 18 March 2020, building on the joint political declaration between the EU and the UK of 2019, proposes a detailed set of rules in these areas. In part they are closely modelled on or inspired by internal EU acquis in the AFSJ, such as the European Arrest Warrant, the "Prüm" cooperation and the Framework Decision of 2006 on simplifying the exchange of information and intelligence between law enforcement authorities ("Swedish Initiative)". The EU has never before concluded such far-reaching co-operation arrangements with a non-Schengen third country. The EU takes the view that it may propose such arrangements since they would be underpinned by a set of strong safeguards, such as an automatic termination in case the UK were to leave the ECHR and suspension should the UK undo domestic incorporation of the ECHR or should the data protection adequacy of the UK law be eroded. That said, even these proposed arrangements consciously stay within certain limits. In particular, the UK would not be granted direct access to EU databases such as the Schengen Information System or that of Europol. The EU's position seeks to ensure that the final agreement would not be censured by the Court of Justice, should the Court consider that the EU cannot 
simply, without any limits, extend the whole framework for cooperation in the AFSJ to a non-Schengen third country. ${ }^{47}$

\section{Setting the limits of mutual trust: the roles of the courts and of the EU legislator}

In the last decade, the main actors who have been involved in setting the limits of mutual trust in schemes of cooperation established in the AFSJ have been the courts. Abundant case law has been developed by the two European Courts, but also by the highest courts of Member States which have not only made preliminary references to the Court of Justice in seminal cases but also occasionally handed down important rulings themselves. ${ }^{48}$ The academic publications on mutual trust have also focused primarily on discussing this evolving case law. Much less scholarly attention has been devoted to how the EU legislator has been dealing with the challenge of setting limits to mutual trust in the various branches of law covered by the AFSJ.

\section{The evolving case law on mutual trust - retrospective and prospective settings}

Many excellent studies have traced the evolution of the case law of both European Courts and their interaction. The question of how far apart the two Courts are to date, or to put it otherwise, whether we see substantially greater convergence between them now as compared to seven years ago, at the time when the Court of Justice formulated its "mutual trust objection" in Opinion 2/13, is a relevant one. This is because the answer may influence the approach in the recently resumed negotiations on the EU's accession to the ECHR (see section 4 below). Quite evidently, points 191 to 194 of Opinion 2/13 are based on the concern, on the part of the judges in Luxemburg, that their counterparts in Strasbourg might, in their case law, not leave enough space for the development of EU law in the AFSJ towards ever more intense cooperation. It is thus worthwhile to ask whether the convergence meanwhile reached is so as to help alleviate those concerns.

Some authors have usefully distinguished between several phases of case law. ${ }^{49}$ In a first phase, many Court of Justice judgements stressed the principle of mutual trust and invoked it to fend off suggestions that authorities of a second Member State should double check compliance with EU law by a first State. Amongst others, the "Aguirre Zarraga" judgment stands for this approach, which contrasted starkly with certain

47 See also, in this context, the Court's strong emphasis on the integrity of the Schengen acquis, notably in CJEU, case C-482/08, UK v. Council, ECLI:EU:C:2010:631.

48 See, inter alia, the judgment of the German Constitutional Court of 15 December 2015, ECLI:DE:BVerfG:2015:rs20151215.2bvr273514 on an Italian European Arrest Warrant for a conviction in absentia; judgment of the UK Supreme Court of 19 February 2014, R (on the application of EM v Secretary of State for the Home Department), [2014] UKSC 12, on suspensions of Dublin transfers to Italy.

49 See in particula Xanthopoulou, CMLR 55 2017/55, pp. 489 - 510. Cf. further, Jacqué, La confiance mutuelle; Meijers Committee, Note on mutual trust and Opinion 2/13 on accession of the European Union to the European Convention on Human Rights (CM 1604) https://www.commissie-meijers.nl/en/comments/406 (14/09/2020). 
case law of the European Court of Human Rights of around the same time. In a second phase, the Court of Justice started accepting unwritten limits to mutual trust. This happened first in the emblematic "N.S." judgment of December 2011, which, echoing the "M.S.S." judgment from Strasbourg earlier that year, ended Dublin transfers of asylum seekers to Greece due to systemic deficiencies of the Greek asylum system. However, during that phase it appeared that the Court's readiness to compromise on mutual trust was conditioned on the existence of systemic problems of fundamental rights in a Member State, a test which the Strasbourg Court never espoused and from which it purportedly distanced itself in the "Tarakhel" judgment of 2013. ${ }^{50}$ Also in 2013, the Strasbourg Court in its decision "Povse v. Austria" 51 did accept the strict system certified judgments ordering immediate return of the Brussels II a regulation, but it relied on the "Bosphorus" presumption, which leaves open whether, upon the EU's accession to the ECHR, such a system would still be found ECHR compliant. In "Avotins v. Latvia," 52 the first relevant judgment of the Grand Chamber of the European Court of Human Rights after Opinion 2/13, the Court combined appreciative words for the principle of mutual trust in the EU with a warning that "limiting to exceptional cases" the power of the Member State of recognition to review the human rights observance of the act of the first Member State could run counter to the ECHR. A third phase is characterised by those judgments of the Court of Justice in which it edged away from the condition of systemic deficiencies and applied limits to mutual trust in situations characterising only certain groups of persons. This phase of stronger convergence between the two European Courts started with the "Aranyosi" judgment of April 2016 in which the Court of Justice admitted an unwritten ground of refusal for European Arrest Warrants and formulated its test in such a way that it also included reported deficiencies affecting only certain groups of people or certain places of detention. More recently, the new approach of allowing an exception to mutual trust also outside systemic problems has been confirmed in the Dublin case law, not least in the "Jawo" judgment. On this basis, commentators have tended to stress the high degree of convergence between the two Courts..$^{53}$

At a closer look, however, the evolving case law is more complex than it initially seems. The three phases did not unfold at the same time for the three main reference areas discussed here - civil law, asylum law and criminal law. In particular, the Court of Justice has not yet relativized its strict stance on the child abduction mechanism as taken in "Aguirre Zarraga", perhaps for want of occasion. Prominent voices consider that, in the light of "Avotins", the European Court of Human Rights would today be prepared to reverse the accommodating stance of "Povse" in this area. ${ }^{54}$ Just how

50 ECtHR, No. 29217/12, Tarakhel v. Switzerland.

51 ECtHR, No. 3890/11, Povse v. Austria.

52 ECtHR, No. 17502/07, Avotins v. Latvia.

53 See, in particular, Lenaerts, pp. $828 \mathrm{ff}$. See also, inter alia, Asta, in: Messina (ed.), pp. 191 211, at pp. 205 f.; Blanchet, pp. 208 ff.; Cortés-Martín, REALAw 2018 (August); Jacqué, Un rapprochement entre la Cour de justice de l'Union européenne et la Cour européenne des droits de l'homme?; Timmermans, pp. $30 \mathrm{ff}$.

54 Callewaert, CMLR 2018/55, p. 1705, considers "Povse" superseded by “Avotins". 
controversial a matter intra-EU child abduction still is, also from the Strasburg view point, is evidenced by debates amongst the judges in recent cases. ${ }^{55}$ General statements about the degree of convergence between the two European Courts are therefore necessarily relative: depending on one's own respective background and preferences, commentators may stress more this or more that general statement of either court, or highlight this judgment from one area or that from another, and come to different conclusions. For example, one may well debate to what extent, in the light of all the case law of the last decade, it is still correct to state that a second check of fundamental rights compliance must be limited to "exceptional cases", an argumentative figure which the Court of Justice continues to uphold - rightly in our view - despite the scepticism voiced from Strasbourg in Avotins. ${ }^{56}$

Nonetheless, we would side with Florence Benoit-Rohmer's finding that there are currently no fundamental differences of approach, but only acceptable nuances between Luxemburg and Strasbourg, and that national courts can, and must, bridge those nuances in their concrete cases of application. ${ }^{57}$ One must also be mindful of the difference in function and method between the two European Courts: whilst the Court of Justice frames the law of the Union through interpretation of EU legislation and general principles, leaving the concrete decision of the case to the national court, the task of the European Court of Human Rights is to assess in each individual case whether or not the applicant was in the end the victim of a human rights violation. Like on other matters, it is key to understand the leading judgments of both European Courts in their respective temporal, sectoral and functional context; ${ }^{58}$ this suggests caution in rushing to conclusions, be it in the sense of a persistent clash of approaches or of full harmony between Luxembourg and Strasbourg. It would rather be more constructive to acknowledge that striking the right balance between the needs of a highly integrated AFSJ relying on mutual trust and of ensuring adequate protection of fundamental rights in each case is a challenge on which all judicial actors in Europe have been gradually progressing, over the last 15 years. Given their efforts and the intense academic debate accompanying them, it would certainly be inadequate to reproach one of the two European Courts for a basic lack of understanding of the other's function and legal framework.

As a modest contribution to the ongoing efforts in developing and evaluating the case law, but also as possible guidance for drafting legislative clauses (see below), we would submit one distinction which might have a certain heuristic value. It is the distinction between retrospective and prospective settings of mutual trust schemes. This distinction may help shed greater light on the idea that a second fundamental rights check should only take place in "exceptional cases".

55 See, e.g., the dissenting opinions of judges Woyticzek and Koskelo in case ECtHR, No. 51312/16, M.K. v. Greece of 2018.

56 Very critical towards that argumentative figure: Nettesheim, p. 9. But see, contra, Larsen, p. 15, making quite a convincing practical argument for sticking to "exceptional cases".

57 Benoit-Rohmer, p. 406.

58 On the importance of contextualisation in understanding case law, see Lepsius, JZ 2019, p. 797. 
By retrospective settings, we mean the classic situation of the execution, by the authorities of one Member State, of a judgment or decision rendered by another Member State. A classic example of this would be a civil judgment under the Brussels I regulation. For the executing authority, from which EU law expects trust, the setting is retrospective because there is an entire case history which has already unfolded in the other Member State. In theory, the authority which is called upon to execute such a judgment or decision could look back and evaluate the case history in the other state. It could, with the help of the authorities of the other Member States, attempt to find out exactly what happened and whether a fundamental rights violation occurred there. However, the question is: should the executing authority become involved in such a labour intensive process? Should it be investing its time, energy and resources probing into what happened in detail? Should it be posing questions to the other Member State? Should it be requesting additional documentation, perhaps even the entire case file, and its translation? These are the hard questions for retrospective cases.

When seeking to answer such questions, there is one key paradigm which must be assessed, namely whether there is a functioning system of domestic remedies in the State that issued the judgment or decision. If such a functioning system exists in principle, i.e. systemic deficiencies are not apparent, and if there is no manifest (or "flagrant") breach of procedural fairness in the individual case concerned, then the judgment or decision can be respected and executed by the other State. In other words, a functioning system of domestic remedies in the issuing State provides the necessary basis for trust in the individual case. Any residual inquiry can then be limited to flagrant breaches of fairness, and, what is more, it appears justified to exclude altogether that the courts of the executing Member State hear material fundamental rights complaints again. In other words, the exceptional case of a double fundamental rights check can, in retrospective settings, be limited to whether judicial control was manifestly dysfunctional in the first Member State to begin with.

Prospective settings, in contrast, are those where the authority of one Member State, the one expected to show trust, finds itself called upon to transfer or surrender a person to another Member State, in fundamental rights-sensitive circumstances, namely in view of a future treatment of the person by the authorities of the other Member States. The classic examples of this are Dublin transfers or European Arrest Warrants in view of criminal prosecution. For these cases, a different paradigm may be useful. In our view, the suitable paradigm to define where mutual trust must find exceptional limits is whether a future fundamental rights violation, in the Member State of destination, is "reasonably foreseeable" 59 for the authority deciding on the transfer or surrender of the person. Only to the extent that it is foreseeable will the fundamental rights violation be legally attributable also to the sending authority and not only to the authority of the State of destination.

The decisive question then is how courts should assess whether, in a given prospective setting, a future fundamental rights violation becomes "reasonably" foreseeable. This will certainly require a case-by-case approach. However, as already indicated by

59 See in particular, Lübbe, pp. $674 \mathrm{ff}$. , and also Wendel, p. 125. 
the use of the qualifying adjective "reasonably", normative considerations can also come into play. These should include the conditions of functioning of the respective scheme of cooperation: should there be room, and if so, to what extent, for a dialogue between the authorities that could lead to "assurances" on the future treatment of the particular applicant? What is the typical basis of information that the "sending authority" can obtain in the respective scheme? Not least, for this paradigm of foreseeability does it matter whether systemic or widespread deficits have been reported in the other State, or whether the applicant can only point to isolated instances of violations and whether the other Member State's bodies are already seen to have tackled them. ${ }^{60}$ Although the Court of Justice was surely right to clarify in its "Dublin" case law that not only systemic deficiencies may warrant an exceptional scrutiny of fundamental rights by the Member State normally expected to trust, it nonetheless remains a relevant factor whether problems are widespread or isolated. If in every single case a person bound to be transferred or surrendered could be heard with any particular argument as to why a fundamental rights violation may loom for him or her, then nothing would remain of the "exceptional" character of the prospective scrutiny of what may happen in the other Member State. Effective judicial review in the other Member State is also one factor to be taken into account in this normative process of assessing which problems are "reasonably" foreseeable for the authority called upon to transfer or surrender a person; but it is a less decisive one than in retrospective cases. For example, if widespread problems of inhuman prison conditions exist in a Member State, then the other Member State cannot simply rely upon the expectation that judicial review in that State, even if independent and fair, will suffice alone to spare the person to be surrendered from such conditions. ${ }^{61}$

One may wonder then whether our suggestion of handling prospective cases is one that comes down to balancing fundamental rights protection with the efficiency of cooperation schemes. We would argue that it is not. The Court has now forcefully excluded such a balancing act in the "Dorobantu" judgment. ${ }^{62}$ However, that judgment seems to confirm that the "foreseeability test" is framed in such a way so as to take normative considerations into account and ensure that the European Arrest Warrant can still function properly. The Court is careful to note that, in the prognostic analysis of a risk of inhuman treatment, only those prisons must be taken into account for which a detention of the person concerned is "concretely envisaged" - in other words, more remote possibilities can be left aside. Furthermore, once the other Member State (which in this instance was Romania) has given "assurances", then in principle one must believe them. That is a normative postulate. The " $L M$ " case is a further example of this as given the systemic problems affecting judicial independence in Poland, one might have concluded that they suffice to presuppose that any Polish

60 Schwarz, p. 138 with a reference to a study by the sociologist Lepsius (Vertrauen zu Institutionen) of 1997: it is not so much a single breach of trust, but the number of unreported breaches of trust, namely systemic toleration and eschewing sanctions, that compromise institutional trustworthiness of authorities towards each other.

61 CJEU, case C-128/18, Dorobantu, ECLI:EU:C:2019:857.

62 See preceding fn. 
court potentially affected by them can no longer offer a fair trial to Mr L.M. in case of his surrender to Poland. The Court of Justice did not go down that route, but instead set out a two-pronged approach, known from Aranyosi, but adapted to the different legal and factual context. A concrete prospective scrutiny of what would happen to Mr LM in Poland was still necessary; dialogues with the Polish authorities were still necessary; but contrary to the prison conditions cases, the Polish replies were not given any value of "assurances". In " $L M$ ", the Court relied on an eminently legal argument: given recital 10 of the Framework Decision, the approach to be developed must not come down to a suspension of the European Arrest Warrant Scheme in relation to Poland. In sum, while in prospective settings like the European Arrest Warrant cases the Court of Justice excludes any balancing between fundamental rights protection and efficiency of the scheme of cooperation once a real risk of violation is found in casu, it nonetheless defines the methods and criteria for assessing such a risk in a flexible manner which is loaded with normative considerations.

The distinction between retrospective and prospective settings, proposed here, is not a summa divisio, which would neatly correspond to differing areas of law or legislative schemes. It is a heuristic tool to assist in understanding how far mutual trust should go and where it should find its limit. To be sure, Dublin transfer cases will normally be prospective settings, and recognition of civil or commercial judgments under Brussels I regulation will be retrospective. For European Arrest Warrants, it may depend on the specific circumstances: the cases discussed above, about a future fair trial in the issuing Member State or about its prison conditions, are prospective ones. In contrast, those Italian in absentia convictions that have caused headaches for the Spanish and the German constitutional courts ${ }^{63}$ stand for the retrospective paradigm, since they are about an alleged human rights violation that has already occurred in the other State. Child abduction cases can have a retrospective or a prospective centre of gravity, depending on whether the gravamen was more an omission to hear a child or a parent in the State of last habitual residence that had issued an order for immediate return or on possible concerns that what may happen to the child once it is returned to that State in the future may not be in the child's best interest. This shows how important the time factor is for an appropriate resolution of child abduction cases. If the child's return can be swiftly decided and implemented, there should be no room for prospective concerns. The presumption should be that the custody rules set by the family courts of the State of last habitual residence are in line with the child's best interest and the authorities in that State can do what is needed to ensure that interest. Only if substantial delay accrues between the abduction and any enforcement of a return, may a gap arise between what the family courts of the last habitual residence once stipulated and the reality for the child's life ever since.

63 See the order of reference leading to the Melloni judgment, CJEU, case C-399/11, Melloni, ECLI:EU:C:2013:107, and the reference in fn. 50 above. 


\section{The role of the EU legislator: between aspiration and reality}

If one understands mutual trust between Member States to be a functional construction principle for cooperation schemes in the AFSJ, then it becomes clearer how primordial the role of the EU legislator is, not only in setting up such cooperation schemes but also in defining the limits to mutual trust. In other words, the EU legislator should reflect and deliberate about clauses which define the instances where the authority of one Member State is authorised, or even obliged, to second-guess whether fundamental rights have really been observed in the other Member State. ${ }^{64}$ It should thus be for the EU legislator to lay down the contours of the "exceptional cases", referred to by the Court in its Opinion 2/13, in which the normal operation of cooperation based on mutual trust cannot prevail. This responsibility of the EU legislators should be a key mission in developing the AFSJ, precisely given the fundamental rights sensitive nature of most cooperation schemes that make for the essence and practical reality of that area. In laying down the extent and limits of mutual trust that are appropriate for each type of cooperation scheme, the EU legislator should provide the necessary legitimacy to the AFSJ, both in terms of "input" and "output legitimacy": on the one hand, through careful, well-informed deliberations in the European Parliament and the Council, legitimacy can be provided for those instances where EU legislation effectively relieves the acting authorities from probing into each and every allegation of risks to fundamental rights in the other cooperating Member State. On the other hand, the legislative deliberations should be informed by the expertise, contributed by the Commission services but much more so by the experts of the Member States' governments coming together in the Council. These experts should discuss "what works" on the ground, i.e., how to ensure, in a way appropriate for each area of the law, that "exceptional" double scrutiny of fundamental rights pleas does not render cooperation too cumbersome. This way, the EU legislator should be able to produce legitimate results in terms of cooperation schemes that take fundamental rights seriously but still provide a high level of efficiency across border law enforcement or a smooth access to and functioning of civil justice between individuals and operators throughout the EU.

So far the ideal aspiration. When looking at the reality, however, i.e. the current state of EU legislation defining the limits of mutual trust, the picture looks somewhat sobering. It seems that the way key EU legislative instruments in the AFSJ have approached this issue so far is marked less by systematic, in-depth reflection and more by puzzling inconsistencies, historical coincidences, sectorial habits and imperfect attempts to codify case law. Some examples may suffice to illustrate these shortcomings and point to the challenges for the future.

One example of how arduous it is to codify case law exists within the current Dublin regulation. In its judgment “N.S.” of 2011, the European Court of Justice had drawn a distinction between claims concerning "any infringement of the individual provisions of the [asylum law] directives" on the hand - these cannot stand in the way of Dublin

64 See also Blanchet, p. 213. 
transfers - and a situation where the authorities of a Member State "cannot be unaware that systemic deficiencies in the asylum procedure and in the reception conditions of asylum seekers in [the responsible] Member State amount to substantial grounds for believing that the asylum seeker would face a real risk of being subjected to inbuman or degrading treatment" within the meaning of the Charter - in the latter case Dublin transfers cannot take place. Based on that case law, the legislator included Article 3(2) in the Dublin III regulation of 2013, an exception whose terms were drafted word by word following the operative part of the "N.S." judgment, and in particular the condition of "systemic deficiencies" (or "flaws"). As already seen, however, subsequently it became clear that the Court would simply not accept Article 3 (2) to express the only possible exception to mutual trust capable of stopping Dublin transfers. While the Court's ruling in the "C.K." case, where a transfer itself would have entailed an atypical risk of inhuman and degrading treatment, was in reality not at all about mutual trust, in its "Jawo" and "Ibrabim" judgments of 19 March 2019, the Court used the occasion to relativize Article 3 (2) and develop a position of principle, according to which "any situation in which there are substantial grounds for believing that the applicant runs such a risk during his transfer or thereafter" would impede a transfer, given the absolute character of the fundamental right in Article 4 of the Charter. In somewhat twisted wording, the Court added that "it cannot be entirely ruled out that an applicant for international protection may be able to demonstrate the existence of exceptional circumstances that are unique to him", in which case a transfer would be barred. This statement is all the more remarkable since in those cases the alleged problems did concern systemic flaws in Italy and Bulgaria. The Court could well have applied a "systemic deficiencies" paradigm and simply made clear that it does not matter whether they exist for the treatment of asylum applicants or of persons having received international protection. One may suspect that the Court wished to use the Jawo and Ibrabim judgments to send a signal of convergence to the European Court of Human Rights. The challenge for the EU legislator is now to see how to adapt Article 3 (2) in the current negotiations about the next version of the Dublin regulation. However, given the convoluted language found in those judgments, that may not be so easy to achieve.

When it comes to judicial cooperation in civil and in criminal matters, one may be astounded by the divergences that become clear when analysing how exceptions from mutual recognition of judgments and decisions, based on alleged fundamental rights problems, are construed in the various acts. To begin with, it is surprising that, whilst in civil law the main EU law instruments, including the Brussels I $a^{65}$ and II a Regulations, until today allow authorities not to enforce judgments based on a general national public policy exception - meanwhile admittedly circumscribed by the Court's case law $^{66}-$, while all instruments of judicial cooperation in criminal matters have consciously left out a comparable ground of refusal based on national public policy. This appears to be counter-intuitive, considering that a civil or commercial

65 Regulation 1215/2012, OJ L 351 of 20/12/2012, p. 1.

66 See only CJEU, case C-7/98, Krombach, ECLI:EU:C:2000:164, at point 37. 
judgment is typically less fundamental-rights sensitive than, say, a European Arrest Warrant. And yet, when the Commission, in its 2009 proposal for a revision of the Brussels I regulation, proposed to do away with that general national public policy exception, the EU legislator rejected that move. It is not clear whether anyone at that time wondered about consistency with what was being construed in criminal law. True, one might say that national grounds for non-recognition of criminal judgments and orders are not necessary given the ongoing programme of harmonisation of criminal procedure, which has no equivalent in civil procedural law. However, the European Arrest Warrant Framework Decision was adopted well before the harmonisation of criminal procedure even began. More plausibly, one could point to the narrower material scope of obligations to recognise judicial orders so far existing in criminal law - while the European Arrest Warrant applies only to a closed list of offences, the Brussels I regulation orders recognition and enforcement of judgments in any civil and commercial matter. It is also true that the criminal law instruments have several optional grounds for non-execution designed to protect typical national concerns. ${ }^{67}$ Still, that does not explain why, in the presently integrated Union and more than 50 years since the Brussels Convention was first introduced, the black-letter law of the Brussels I a regulation should still allow one Member State to refuse enforcing the most insignificant civil judgment of another Member State for going against its own public policy.

Furthermore, within the area of judicial cooperation on criminal matters, too, one can hardly overlook certain legislative inconsistencies. The European Arrest Warrant Framework Decision of 2002 includes no ground for refusal to execute an Arrest Warrant based on a general fundamental rights concern. It only features the general reference to fundamental rights in Article 1 (3), as a seemingly declaratory confession that the Framework Decision shall not modify the obligation to respect fundamental rights. The omission of a fundamental rights-based ground of refusal was entirely purposeful in 2002, as is clear from recital 10 of the Framework Decision, according to which the mechanism of the European Arrest Warrant is based on a high level of confidence between Member States and its implementation may be suspended only in the event of a serious and persistent breach by a Member State determined in the special procedure of Article 7 TEU. In contrast, in 2014 the Directive establishing the European Investigation Order (“EIO”), recognised a general, widely formulated ground for refusal in Article 11 (f) applying "if there are substantial grounds to believe that the execution of the investigative measure indicated in the EIO would be incompatible with the executing State's obligations in accordance with Article 6 TEU and the Charter". This was provided for even though a European Investigation Order, in a typified assessment, tends to be less fundamental rights-sensitive than a European Arrest Warrant.

In 2018, the two Legal Services of the European Commission and the Council, in informal contacts with one another, took stock of the above highlighted inconsistencies in EU legislation and resolved to work towards advising the EU legislator to make 
more conscious and more rational choices on the limits of mutual trust in the AFSJ. This should be done through legislative clauses that would be tailor-made to the respective context. The first opportunity to do so presented itself in the area of criminal law, where the Commission had tabled a proposal for a Regulation on the mutual recognition of freezing orders and confiscation orders, ${ }^{68}$ an initiative which gave rise to the first EU regulation ever in the area of criminal law. ${ }^{69}$ The Commission's proposal came with a detailed assessment of its fundamental rights conformity, pointing to various specific safeguards in the proposal, including grounds of refusal of recognition for ne bis in idem and in absentia proceedings, and recalling all the directives on harmonisation of criminal procedural law adopted since 2010. It also featured, in Article 1 (2), the same kind of declaratory clause on the obligation to respect fundamental rights not being modified by the regulation that one finds in Article 1 (3) of the European Arrest Warrant Framework Decision. In light of all this, the Commission did not find it appropriate to include a general ground for refusal of recognition based on fundamental rights in its proposal. Nonetheless, in the negotiations the European Parliament, as well as a few delegations in the Council, requested to include the same general ground for refusal as found in the "EIO" directive of 2014. In parallel, one delegation in the Council pushed, as it does in many other files, for a further specific clause permitting non-recognition based on national rules on the freedom of the press and of other media (known as the "Swedish clause"). These positions could legitimately be questioned in this particular setting: the effects of freezing orders and confiscation orders resulting from criminal proceedings are limited to the patrimonial sphere and thus typically present a lower risk of fundamental rights intrusion than European Arrest Warrants, but also than the EIO scheme of cooperation, which can be used in any type of criminal procedure and therefore contribute to the most severe criminal convictions. What is more, the range of fundamental rights possibly at risk seemed much narrower for this new scheme of cooperation: it was, on the one hand and mainly, linked to problems regarding a fair trial in the criminal procedure of the State requesting recognition of its freezing or confiscation order (i.e., a retrospective setting), and perhaps on the other hand and in extreme situations, to disproportionate effects of freezing or confiscation on the economic situation of the person affected by recognition and enforcement, perhaps even of its minimum social subsistence (i.e. a prospective setting). So the case would have been strong to try, as a compromise, to draft a targeted, tailor-made clause addressing the limited potential of this new scheme of cooperation to put fundamental rights at risk, and thereby to give meaning to what the Court evoked in Opinion 2/13, namely that the fundamental rights compliance of an act posed by one Member State should as a rule not be scrutinised again by the other Member State. A replication of the "Swedish clause" in this regulation also appeared questionable: criminal-law based orders to confiscate property that constitutes proceeds or instrumentalities of crime hardly represent an intrinsic threat to freedom

$68 \operatorname{COM}(2016) 819$ final.

69 Regulation 2018/1805 on the mutual recognition of freezing orders and confiscation orders, OJ L 303 of 28/11/2018, p. 1. 
of expression and of the media more than to other fundamental rights, and it was even less clear why there would be a need for a national law-based ground of refusal on this particular fundamental right in this specific legislative context. ${ }^{70}$ Despite these arguments however, the result of the legislative procedure was that the Swedish clause yet again found its way into the final regulation. More significantly, a non-targeted, general ground of refusal based upon fundamental rights was included, only that, as compared to the wording in the EIO Directive of 2014, its wording is somewhat more restrictive. The finally agreed clause evokes "exceptional situations", and it requires showing, "on the basis of specific and objective evidence, that the execution of the confiscation order would, in the particular circumstances of the case, entail a manifest breach of a relevant fundamental right". The clause also adds, though non-exhaustively, "the right to an effective remedy, the right to fair trial or the right of defence".${ }^{71}$ With this, the legislator gives an indication that it sees the scope of this clause as covering retrospective settings of exceptional fair trial problems or deficiencies of effective remedies in the issuing Member State, whereas non-recognition based on prospective concerns of impact on economic and social rights of the person affected by the order should be foreclosed, all the more since Article 1 (3) of the Regulation attributes the task of ensuring proportionality to the issuing authority only. ${ }^{72}$

Overall, the Regulation of 2018 on mutual recognition of freezing orders and confiscation orders may be seen as a small step towards a more in-depth, rational and context-based reflection in the legislative process on how to set the right limits to mutual trust between Member States in respect to fundamental rights. That being said, the general impression derived from the debates in this and in other legislative procedures, is that far-reaching attempts to draft narrower, tailor-made clauses on the limits of mutual trust in EU legislation will remain difficult, if not futile, as long as the notorious rule of law problems persist in some Member States. Due to the high level of general distrust towards such Member States, certain delegations in the Council and the European Parliament are calling for the inclusion of broad clauses that can operate as general safety valves, and they are ready to accept the losses of efficiency in practical cooperation that may be caused by such clauses. There is clearly much less mutual trust amongst the Member States to date in their respective capacity and willingness to ensure respect for fundamental rights in the AFSJ than there was 15 years ago.

Only the civil law practitioners seem to live in a slightly different world, as is evidenced by our last and most recent legislative example. It is Regulation 2019/111173

70 Lenaerts, p. 814 warns about a Member State imposing its own constitutional standards on the Member State issuing a EAW (“...would be the beginning of the end of the principle of mutual trust").

71 See Article 8 (1)(f) and Article 189 (1)h) of the Regulation. Emphasis added.

72 See also Recital 34, last sentence: "The right to property should, in principle, not be relevant because freezing and confiscation of assets necessarily imply an interference with a person's right to property and because the necessary safeguards in that respect are already provided for in Union law, including in this Regulation.”.

73 Regulation 2019/1111 on jurisdiction, the recognition and enforcement of decisions in matrimonial matters and the matters of parental responsibility, and on international child abduction, JO L 178 of 02/07/2019, p. 1. 
with its new rules on international child abduction, applicable from August 2022, which will replace the mechanism of the current Brussels II a regulation. Here the Council, after three years of intense negotiations, revised the mechanism of "unconditional trust" which had been applied in the "Aguirre Zarraga" case. Interestingly, the new Regulation, in its section on "certain privileged decisions" " does largely confirm that the court of last habitual residence of the abducted child should have the final say when it orders the return of the child. That order, as in "Brussels II a", is automatically recognised and must be enforced without any possibility by the authorities of the other Member State to call into question its fundamental rights compliance. However, pursuant to Regulation 2019/1111, this will apply only if that court speaks through a judgment finally settling the custody rights, rather than through an interlocutory order merely imposing the return of the child as in the Brussels II a regulation. Moreover, the new Regulation includes a range of new safeguards, in particular to ensure that the child is always offered a "genuine and effective opportunity" to be heard ${ }^{75}$ and that the court of last habitual residence, before ordering a return in a decision settling custody rights, takes into account the facts and reasons set out in the prior judicial decision from the other Member State (whereto the child has been abducted ${ }^{76} .{ }^{77}$ It is noteworthy that the Council arrived at that result despite the fact that the Commission's proposal was based on an entirely different philosophy, as it would have allowed the courts of the State whereto the child was abducted to refuse enforcement of a return order in certain cases, namely if the child "being of sufficient age and maturity now objects" or "other circumstances have changed to such an extent ... that its enforcement would now be manifestly incompatible with the best interests of the child". ${ }^{78}$

It will be interesting to observe whether this new legislative choice, based largely upon an automatism and still mandating "unconditional trust" to the decision of the court of last habitual residence, will be better accepted than the Brussels II a Regulation by the two European Courts ${ }^{79}$ and, not least, by the family courts on the ground. Presumably, the decisive factor for the success of this future system will be the time factor, i.e. whether children illegally abducted can be returned more quickly once the court of the State of last habitual residence, after a fair procedure, settled custody and ordered return.

74 Articles $42 \mathrm{ff}$. of the Regulation.

75 See Article 21 of the Regulation. The words "genuine and effective opportunity" may be taken as an implicit reaction to the facts of the "Aguirre Zarraga" case.

76 Article 47 (4) of the Regulation.

77 Further safeguards in the new Regulation include the detailed requirements in Article 47 (3) that the court of last habitual residence must observe before issuing the certificate ordering return of the child, especially for cases of default in appearance, and the mandatory refusal of recognition and enforcement in case the decision is irreconcilable with a subsequent decision on parental responsibility (Article 50).

78 See Article 40 (2) of the Commission's proposal, COM(2016) 411 final.

79 See fn. 53, 56 and 57 above. 


\section{E. The EU's accession to the ECHR: an obstacle to mutual trust or a catalyst for it?}

In Opinion 2/13, the European Court of Justice identified the ECHR, or more precisely, a problematic future development under the ECHR, as an obstacle to the operation of such EU law that imposes mutual trust between Member States. The problematic development would be that the ECHR would require one Member State to check that another Member State has observed fundamental rights, where EU law had excluded that check. That development, it concluded, would upset the underlying balance of the EU and undermine its autonomy. Thus, in Opinion 2/13 the principle of mutual trust became an obstacle to the EU's accession to the ECHR, at least pursuant to a draft accession agreement containing nothing to prevent the identified problematic development.

As lucidly observed by Jean-Paul Jacqué, ${ }^{80}$ this objection of the Court of Justice to the draft accession agreement is of a different nature to most of the other objections in Opinion 2/13. Its source is a concern about divergence of case law between the two European Courts on cases where mutual trust-based schemes of cooperation between Member States are applied. The objection is connected to substantive human rights law, and not to any particular institutional or structural aspect of the EU's accession to the ECHR. If the problem is real, then it already exists today, even in the absence of accession. ${ }^{81}$ At most, accession might exacerbate it, if one assumed that, after accession, the European Court of Human Rights would no longer accord the "Bosphorus" presumption to EU acts and apply full scrutiny to Member State action limited to implementing them without any residual discretion. But the fate of the "Bosphorus" case law after accession is itself an open question, and the Strasbourg Court is well capable of modulating the depth of its scrutiny under "Bosphorus", as illustrated by the Avotins judgment. ${ }^{82}$

However, as noted above, since 2014 when the Opinion was rendered, both Courts have been converging in their case law, up to the point that some wonder whether there is still any issue remaining that would need to be explicitly resolved in the accession agreement itself. ${ }^{83}$ On the other hand, case law may again evolve over time, and the "mutual trust" objection in Opinion 2/13 was clearly one formulated with constitutional emphasis. The EU should not take the risk of being censured in another opinion procedure on accession for not having done its homework seriously. It is

80 On the following, see in particular Jacqué, Europe des droits \& libertés/Europe of Rights \& Liberties 2020/1, pp. 27-40.

81 See also Meijers Committee, Note on mutual trust op. cit. fn. 49. In that regard, it is similar to the problem linked to Protocol $n^{\circ} 16$ of the ECHR, see points 196 to 199 of Opinion $2 / 13$.

82 See the detailed discussion of the facts of the case the Court deploys for its findings that the EU's control mechanisms had deployed their full potential and that there was no manifestly deficient protection.

83 Jacqué, Europe des droits \& libertés/Europe of Rights \& Liberties 2020/1; Timmermans, p. 32 . 
therefore appropriate for the EU to seek a solution in the negotiations about amendments to the accession agreement which have recently resumed.

Amongst the possible solutions discussed, ${ }^{84}$ one idea is to attempt to negotiate a sort of "disconnection clause" into the accession agreement, covering relations between EU Member States governed by EU law based on the mutual trust principle. In its crudest form, namely imagining a clause similar to typical disconnection clauses as we know them from certain Council of Europe Conventions, such a clause would come down to a rather drastic carve-out from the ECHR, covering important sectors of EU Member States' action and probably also of EU legislation itself. Such a carveout would be claimed for most fundamental rights-sensitive laws such as the European Arrest Warrant Framework Decision, the Dublin Regulation, etc. Leaving apart that the non-EU contracting parties to the ECHR could certainly not accept such a proposal, it would be incompatible with the very nature of the ECHR and lead to a significant backlash in the protection of fundamental rights in Europe. It would hence betray the very purpose of the EU's accession to the ECHR, which was only to close currently existing gaps in human rights protection as regards to the acts of EU institutions. Seen in this light, such a clause would not only clash with the fundamental character of the ECHR, but also with EU primary law and notably Article 6 (2) TEU. Such a solution cannot be assumed to be what the Court of Justice wished to imply in Opinion 2/13. ${ }^{85}$

To be sure, more refined variants of the "disconnection clause" idea could also be imagined in theory, aimed not at carving out altogether Member State action based upon schemes of cooperation such as the ones discussed in this study, but at eliminating, for the purposes of ECHR scrutiny, their cross-border element. In other words, one would attempt to exclude that, under the ECHR, ensuring respect for fundamental rights is a matter for both EU Member States participating in a cooperation scheme in the AFSJ rather than only one of them. This could theoretically be achieved by a clause that would attribute ECHR responsibility, and thus the role of defending the whole case in Strasbourg, exclusively to one of the two cooperating Member States, be it to the first - e.g., the State that issued a European Arrest Warrant - or to the second - e.g. the State that executed the Warrant. Apart from representing a major intrusion into the normal functioning of the ECHR system and hence its likelihood to be rejected in the negotiations, any such clause would however be unworkable in practice. Indeed, as we have seen in this study, in reality the picture is never as black or white as it may initially appear. Mutual trust obligations are almost never absolute - EU law requires no blind trust as K. Lenaerts put it, but rather doses of trust modulated in manifold ways according to what the EU legislator specifies sector by sector, scheme by scheme. It would be near impossible to capture such a multifaceted reality of EU law in one mere clause attributing a concrete case, in its

84 The ideas discussed in the following passages of this piece were floated in oral interventions at workshops attended by the author. For a critical discussion of the idea of a "disconnection clause”, see also Cortés-Martín, REALAw, 2018 (August).

85 Likewise, Timmermans, p. 33 ("unimaginable that this would be the purport of the Opinion”). 
entirety, only to one of the two Member States. Moreover, an EU Member State would hardly enjoy the prospect of having to defend, in the Strasbourg Court, a set of facts and action which took place in another Member State, beyond its own control, and about which it had little knowledge.

One further idea could be to codify the current "Bosphorus" presumption in favour of EU law imposing obligations of mutual trust organising cooperation between Member States in the AFSJ. Given that the Bosphorus principle has been applied by the Strasbourg Court in cases such as "Povse" or "Avotins", such a clause, it could be argued, would sufficiently protect the EU's autonomy. However, this approach would also have its potential downsides. Very wisely, from the outset of the EU accession negotiations both sides agreed not to thematise whether, after accession, the "Bosphorus" case law could still be applied in favour of the EU. Putting forward such a proposal would interfere with that agreed manner of proceeding and would lead to extremely difficult discussions about double standards within the ECHR system. Even if such a clause could be agreed, it might very well go against the EU's own wider interests, as it would then allow a strong e contrario conclusion that outside the scope of the clause the Bosphorus case law is superseded by the accession agreement. "Bosphorus" would then no longer be available in situations where other fundamental principles of EU law might be at stake. With such a special derogatory clause imposing a reduced standard of scrutiny on account of one EU constitutional principle, namely mutual trust, the EU could hardly expect an accommodating stance of the Strasbourg Court in other cases touching on other fundamental EU principles.

This study argues for another avenue which could be more promising than those discussed above. It could be a combination of a substantive clause on mutual trust and of procedural means ensuring that the EU and its Member States can deal appropriately with cases on mutual trust arising in the Strasbourg Court. First, there could be a clause in the accession agreement reflecting the fundamental importance of the principle of mutual trust between EU Member States and fleshing out what this principle may entail under Union law. Through such a clause, the content of the mutual trust principle would be firmly anchored in the substantive law of the ECHR to be applied by the Strasbourg Court. Such a substantive solution appears to be appropriate for what is primarily a substantive law concern rather than an institutional one. Fortunately, the clause could be inspired not only by wording from Opinion 2/13, but also by statements of the Strasbourg Court itself in its “Avotins" judgment where it recognised the importance of mutual trust for the AFSJ. Therefore, the non-EU contracting parties to the ECHR should not have difficulties to accept such a clause. The clause could, secondly, be buttressed by the procedural means which the accession agreement will include, notably the co-respondent mechanism and the prior involvement, adapted as they will be in the light of the guidance given in Opinion $2 / 13 .{ }^{86}$ These procedures will ensure that, in a case brought in Strasbourg where Union legislation requires one Member State to presume that fundamental rights have been respected by another without checking such respect anew, the party which itself brought about that state 
of affairs, i.e. the Union, also assumes responsibility for it under the ECHR. ${ }^{87}$ The "prior involvement" procedure will ensure that the Court of Justice will first have its say in a concrete case, in order to check the human-rights conformity of the legislation at stake and to interpret it in a human-rights friendly manner, if required. As a contracting party with full rights and backed by the authority of a Court of Justice ruling, the EU will be able to defend and explain, in the Strasbourg Court, its legislation organising mutual trust in a much more forceful manner than can be done today by a Member State agent acting as a "straw man".

This leads to our last proposition. Based upon a re-negotiated agreement along the lines just mentioned, the EU's accession to the ECHR may be seen as a catalyst for mutual trust between EU Member States, promoting the smooth operation of legislative schemes based upon that principle, rather than as an obstacle to it. This is for a two reasons. First, while today, in the absence of accession, the EU and its Member States are not exempt from any risk of Strasbourg Court rulings diverging from those of Luxembourg on AFSJ matters and exposing the Member States to conflicting obligations, ${ }^{88}$ after accession the EU itself will, as co-respondent with full party rights, explain and defend more convincingly the choices made by the EU legislator in organising the AFSJ to the Strasbourg Court. Secondly, the EU's accession will strengthen the unique pan-European system of human rights protection enshrined in the ECHR institutionally, financially, and symbolically. This would be more than welcome in times where novel, worrying rifts appear in Europe and within the EU on the rule of law and other core values. Mutual trust between Member States, and EU legislation based upon it, cannot be sustained in the long run when those rifts are becoming deeper. For all its remarkable recent case law in the area of judicial independence, the European Court of Justice alone cannot be expected to carry the full burden of upholding the rule of law. This requires robust, constructive interaction between the three judicial poles, each endowed with undisputable authority and integrity: the European Court of Justice, the European Court of Human Rights and the national constitutional and supreme courts. The EU's accession to the ECHR can build trust between these three judicial poles.

\section{F. Conclusion}

When looking in detail at the principle of mutual trust in the AFSJ, its legal value appears more limited than what the ductus of the Court's Opinion 2/13 may suggest. It needs differentiation, and above all it needs implementation. As a functional construction principle for the AFSJ, it remains a significant challenge for the EU legislator, who has a great deal of work to do in defining more consistent rules. For this to happen, it will be paramount to overcome the current rule of law problems in some of the Union's Member States. Our highest courts in Europe, namely the two European Courts and the national constitutional and supreme courts, also need to intensify their

87 Timmermans, p. 33.

88 See only Jacqué, Europe des droits \& libertés/Europe of Rights \& Liberties 2020/1. 
dialogue ${ }^{89}$ both formally and informally, to find converging solutions on how to uphold fundamental rights in highly integrated, trust-based schemes of cooperation. To attain this, the highest courts themselves need to preserve and strengthen their mutual trust in one another. The EU's accession to the ECHR would, amongst other matters, have the virtue to facilitate such trust.

\section{BIBLIOGRAPHY}

ASTA, GABRIELE, I limiti al principio di mutual fiducia nell'ambito dello spazio di libertà, sicurezza e giustizia, in: Messina, Michele (ed.), I valori fondanti dell'Unione europea a 60 anni dai trattati di Roma, 2017, pp. 191-211

BARTOLINI, SILVIA, In The Name Of The Best Interests Of The Child:The Principle Of Mutual Trust In Child Abduction Cases, Common Market Law Review, 2019, Vol. 56, pp. 91-120

BENOÎT-ROHMER, FLORENCE, Les cours européennes face au défi de la confiance mutuelle, Revue trimestrielle des droits de l'homme, 2017, Vol. 110, pp. 391-406

BLANCHET, THÉRÈSE, Aie confiance! - La confiance mutuelle peut-elle se décréter?, in: Czuczai, Jenő ; Naert, Frederik (eds.), The EU as a Global Actor, Liber Amicorum in Honour of Ricardo Gosalbo Bono, Leiden, 2017, pp. 174-214

BOGDANDY, ARMIN VON, Vertrauen im europäischen Rechtsraum, in: Verfassungskrisen in der Europäischen Union, Kadelbach, Stefan (ed.), Baden-Baden, 1. Aufl., 2018, pp. 23-40.

CALLEWAERT, JOHAN, Do we still need Article 6(2) TEU? Considerations on the absence of EU accession to the ECHR and its consequences, Common Market Law Review, 2018, Vol. 55, pp. 1685-1716

DANWITZ, LUC VON, Der Grundsatz des gegenseitigen Vertrauens zwischen den Mitgliedstaaten der EU. Eine wertebasierte Garantie der Einheit und Wirksamkeit des Unionsrechts, Europarecht, 2020, Vol. 1, pp. 61-89

JACQUÉ, JEAN PAUL, Encore un effort camarades... L'adhésion de l'Union à la Convention européenne des droits de l'homme est toujours à votre portée, Europe of Rights and Liberties/Europe des droits \& Libertés, 2020, Vol. 1, pp. 27-40

JACQUÉ, JEAN PAUL, La confiance mutuelle - un élément fédéral dans l'Union européenne, in : Penser les droit à partir de l'individu, mélanges en l'honneur d'Elisabeth Zoller, Dalloz 2018, pp. 81-99

JACQUÉ, JEAN PAUL, Un rapprochement entre la Cour de justice de l'Union européenne et la Cour européenne des droits de l'homme?, available at : http://www. droit-union-europeenne.be/416703027 (14/09/2020)

89 On the importance of this dialogue for the successful operation of the principle of mutual trust and the effective protection of fundamental rights, see Lenaerts, p. 838. 
LADENBURGER, CLEMENS, The Principle of Mutual Trust in the Area of Freedom, Security and Justice: Some Reflections on its Corollaries, in: Lenaerts, Koen; Bonichot, Jean-Claude; Kanninen, Heikki; Naômë, Caroline; Pojhankoski, Pekka (eds.), An Ever-Changing Union? Perspectives on the Future of EU Law in Honour of Allan Rosas, Oxford, 2019, pp. 163-176

LADENBURGER, CLEMENS; ALBUS, VALERIE, EU Law Impact on Criminal Procedure, in: Sarmiento, Daniel; Ruiz-Fabri, Hélène; Hess, Burkhard (eds.), Yearbook on Procedural Law of the Court of Justice of the European Union, 2020 (forthcoming)

LARSEN, LARS BAY, Quelques remarques sur la place et les limites de la confiance mutuelle dans le cadre du mandat d'arrêt européen, L'observateur de Bruxelles, 2018, Vol. 112, pp. 10-15

LENAERTS, KOEN, La vie après l'avis: Exploring the Principle of mutual (yet not blind) Trust, Common Market Law Review, 2017, Vol. 54, pp. 805-840

LEPSIUS, OLIVER, Kontextualisierung als Aufgabe der Rechtswissenschaft, Juristenzeitung, 2019, Vol. 74, pp. 793-802

LÜBBE, ANNA, Mutual trust" und die Folgen des Aufenthaltsbeendigungshandelns, Neue Zeitschrift für Verwaltungsrecht, 2017, Vol. 10, pp. 674-680

MAIANI, FRANCESCO ; MIGLIORINI, ANDREA, One Principle to Rule Them All? Anatomy of Mutual Trust in the Law of the Area of Freedom, Security and Justice, Common Market Law Review, 2020, Vol. 57, pp. 7-44

NETTESHEIM, MARTIN, Überdehnt der EuGH den Grundsatz gegenseitigen Vertrauens?, Zeitschrift für Europarecht, 2018, pp. 4-21

PRECHAL, SASCHA, Mutual Trust before the Court of Justice of the European Union, European Papers, 2017, Vol. 2, pp. 75-92

REGAN, EUGENE, The role of the principles of mutual trust and mutual recognition in EU law, Diritto dell'Unione europea, 2018, Vol. 2, pp. 231-247

SCHMIDT-ASSMANN, EBERHARD, Vertrauen in und durch Recht, in: Weingardt, Markus (Hrsg.), Vertrauen in der Krise, 1.Aufl., Baden-Baden, 2011, pp. $129-150$

SCHWARZ, MICHAEL, Let's talk about trust, baby! Theorizing trust and mutual recognition in the EU's area of freedom, security and justice, European Law Journal, 2018, Vol. 24, pp. 124-141

TIMMERMANS, CHRISTIAAN, How Trustworthy is Mutual Trust? Opinion 2/13 Revisited, in: Lenaerts, Koen; Bonichot, Jean-Claude; Kanninen, Heikki; Naômë, Caroline; Pojhankoski, Pekka (eds.), An Ever-Changing Union? Perspectives on the Future of EU Law in Honour of Allan Rosas, Oxford, 2019, pp. 21-34.

WENDEL, MATTIAS, Rechtsstaatsaufsicht und gegenseitiges Vertrauen, Europarecht, 2019, Vol. 1, pp. 111-132 
XANTHOPOULOU, ERMIONI, Mutual trust and rights in EU criminal and asylum law: Three phases of evolution and the uncharted territory beyond blind trust, Common Market Law Review, 2018, Vol. 55, pp. 489-509 
